\title{
Evidence for oxic conditions during oceanic anoxic event 2 in the northern Tethyan pelagic realm
}

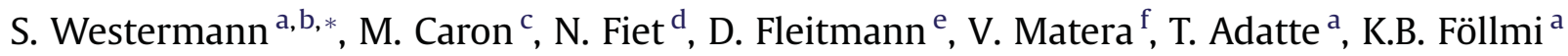 \\ a Institute of Geology and Paleontology, University of Lausanne, Anthropole, 1015 Lausanne, Switzerland \\ ${ }^{\mathrm{b}}$ Department of Earth Sciences, University of Bristol, Queen's road, BS8 1RJ, Bristol, UK \\ ${ }^{\mathrm{c}}$ Department of Geosciences, University of Fribourg, Pérolles, 1700 Fribourg, Switzerland \\ ${ }^{\mathrm{d}}$ AREVA, 33 rue La Fayette, 75009 Paris, France \\ ${ }^{\mathrm{e}}$ Institute of Geological Sciences, University of Bern, Baltzerstrasse 1-3, 3012 Bern, Switzerland \\ ${ }^{\mathrm{f}}$ INRS, Av. de Bourgogne, 54500 Vandoeuvre-Les-Nancy, France
}

Upper Cenomanian pelagic sediments from the northern Alpine Helvetic fold-and-thrust belt (northern Tethyan margin) coeval with Oceanic Anoxic Event (OAE) 2 are characterized by the temporal persistence of micrite sedimentation and lack of organic carbon-rich layers. We studied an expanded section in the Chrummflueschlucht (east of Euthal, Switzerland), which encompasses the OAE 2 time interval. In order to identify the paleoceanographic and paleoenvironmental conditions during OAE 2 in this part of the northern Tethyan margin, and more specifically to trace eventual changes in nutrient levels and oxic conditions, we investigated the biostratigraphy (planktonic foraminifera), the bulk-rock mineralogy, and measured stable carbon- and oxygen-isotopes, total phosphorus $(\mathrm{P})$ and redox-sensitive trace-element (RSTE) contents.

We were able to determine - with some remaining uncertainties - the different planktonic foraminiferal biozones characteristic of the Cenomanian-Turonian boundary interval (Rotalipora cushmani, Whiteinella archaeocretacea and Helvetoglobotruncana helvetica zones). In the lower part of the section ( $R$. cushmani total range zone), the bulk-rock $\delta^{13} \mathrm{C}$ record shows a long-term increase. Within sediments attributed to the $W$. archaeocretacea partial range zone, $\delta^{13} \mathrm{C}$ values reach a maximum of $3.3 \%$ (peak "a"). In the following the values decrease and increase again to arrive at a plateau with high $\delta^{13} \mathrm{C}$ values of around $3.1 \%$, which ends with a peak of $3.3 \%$ (peak "c"). At the top of the section, in sediments belonging to the $H$. helvetica total range zone, $\delta^{13} \mathrm{C}$ values decrease to post-OAE values of around $2.2 \%$. The last occurrence of $R$. cushmani is observed just above the positive $\delta^{13} \mathrm{C}$ shift characterizing OAE 2 .

$P$ contents display small variations along the section with a long-term decreasing trend towards the top. Before the OAE 2 interval, P values show higher values and relatively good covariation with detrital input, indicating higher nutrient input before OAE 2. In sediments corresponding to the onset of the $\delta^{13} \mathrm{C}$ positive excursion, $\mathrm{P}$ content is marked by a sharp peak probably linked to a slowdown in sedimentation rates and/or the presence of a small hiatus, as is shown by the presence of glauconite and phosphatic grains. In the interval corresponding to OAE 2, P values remain low and increase slightly at the end of the positive shift in the $\delta^{13} \mathrm{C}$ record (in the $H$. helvetica total range zone).

The average contents of RSTE ( $\mathrm{U}, \mathrm{V}, \mathrm{As}, \mathrm{Co}$, Mo and Mn) remain low throughout the section and appreciable RSTE enrichments have not been observed for the sedimentary interval corresponding to OAE 2. No correlation is observed with stratigraphic trends in RSTE contents in organic-rich deeper-water sections. The presence of double-keeled planktonic foraminifera species during most of the Cenomanian/Turonian boundary event is another evidence of relatively well-oxygenated conditions in this part of the northern Tethyan outer shelf.

Our results show that the Chrummflueschlucht section corresponds to one of the most complete section for the Cenomanian-Turonian boundary interval known from the Helvetic realm even if a small hiatus may be present at the onset of the $\delta^{13} \mathrm{C}$ record (peak "a"). The evolution of $\mathrm{P}$ contents suggests an increase in input of this nutritive element at the onset of OAE2. However, the trends in RSTE contents and the planktonic foraminifera assemblages show that the Helvetic realm has not been affected by strongly depleted oxygen conditions during OAE 2.

\footnotetext{
* Corresponding author. Department of Earth Science, University of Bristol, Queen's road, BS8 1RJ Bristol, UK. E-mail address: stephane.westermann@bristol.ac.uk (S. Westermann).
} 


\section{Introduction}

According to the original definition by Schlanger and Jenkyns (1976), oceanic anoxic events (OAEs) represent exceptional episodes in Earth's history, which are marked by widespread dysoxic to anoxic conditions in the world oceans. These events resulted in the extensive deposition of organic-rich sediments and changes in the dynamics of the global carbon cycle leading, for instance, to changes in the relative importance of inorganic and organic-carbon reservoirs. The driving mechanisms behind OAEs are still under debate. In the case of the formation of Cretaceous black shales, different models have been proposed including - either alone or in combination - large-scale increases in primary productivity, world-wide expansion of oxygen-minimum zones and the intensification of water-column stratification (Schlanger and Jenkyns, 1976; Arthur and Schlanger, 1979; Jenkyns, 1980; Scholle and Arthur, 1980; Bralower and Thierstein, 1984; Pederson and Calvert, 1990; Jenkyns, 2003; Pancost et al., 2004; Hardas and Mutterlose, 2007; Pearce et al., 2009). Recently, the stratigraphic distribution of redox-sensitive trace elements (RSTE; e.g., U, V, As, Mo and Co) has been explored in OAE-related sediments throughout the Mesozoic, in order to trace the temporal and spatial evolution in oxygen contents (Algeo and Maynard, 2004; Bodin et al., 2007; Brumsack, 2006; Algeo and Maynard, 2008). In addition, the evolution in phosphorus (P) contents and accumulation rates has been employed to trace both changes in the marine $P$ cycle and their impact on primary productivity rates, as well as the influence of anoxic bottom-water conditions on the capacity of the sedimentary reservoir to retain P (Ingall and Van Cappellen, 1990; Van Cappellen and Ingall, 1994; Mort et al., 2007). These two approaches represent valuable tools in unravelling the paleoceanographic and paleoenvironmental conditions during OAEs (e.g., Turgeon and Brumsack, 2006).

The Late Cenomanian sedimentary record encompasses one of the best-studied OAEs, labelled OAE 2 (Schlanger and Jenkyns, 1976; Jenkyns, 1980; Schlanger et al., 1987; Jenkyns et al., 1994; Strasser et al., 2001; Leckie et al., 2002; Sageman et al., 2006; Caron et al., 2006; Mort et al., 2007; Voigt et al., 2007; Adams et al., 2010; Montoya-Pino et al., 2010). Major climatic and paleoceanographic changes have been associated with this event (Jenkyns et al., 1994; Huber et al., 2002; Norris et al., 2002; Forster et al., 2007). The onset of OAE 2 is characterized by an important positive excursion in the $\delta^{13} \mathrm{C}$ carbonate bulk-rock record of approximately $2.5 \%$ (Schlanger and Jenkyns, 1976; Jenkyns, 1980; Schlanger et al., 1987; Gale et al., 1993; Erbacher et al., 1996; Jarvis et al., 2006; Voigt et al., 2006). OAE 2 is also marked by an extinction event and turnover in planktonic foraminifera, radiolaria and nannofossil assemblages (Eicher and Worstell, 1970; Hart and Bigg, 1981; Caron and Homewood, 1992; Leckie, 1985; Hart and Ball, 1986; Lamolda et al., 1997; Grosheny and Malartre, 1997; Keller et al., 2001; Leckie et al., 2002; Erba, 2004; Caron et al., 2006; Grosheny et al., 2006), a sealevel rise (Haq et al., 1987) and a decrease in the ${ }^{87} \mathrm{Sr} /{ }^{86} \mathrm{Sr}$ ratio (Jones and Jenkyns, 2001). Recently, Mort et al. (2007) showed that the onset of OAE 2 correlates with a general increase in P-accumulation rates, which may have triggered an overall increase in sea surface-water productivity.

The northern Alpine Helvetic thrust-and-fold belt representing the central part of the northern Tethyan margin remains an underexplored area with regards to the OAE 2 . This may be related to the observation that organic-rich sediments and any other obvious change in the lithological and mineralogical composition are lacking in the corresponding formation (Seewen Formation; Bolli, 1944; Föllmi and Ouwehand, 1987; Delamette, 1988; Föllmi, 1989). This is in contrast to more distal shelf areas on the northern Tethyan margin, which are presently locked up in
Ultrahelvetic units (Wagreich et al., 2008), and from the Brianiçonnais domain ("Préalpes médianes"; Strasser et al., 2001), from which organic-rich sediments related to OAE 2 have been described.

We selected a well-preserved and expanded section in the Chrummflueschlucht (central Switzerland), in order to study paleoenvironmental change during OAE 2 in the Helvetic pelagic environment, which does not appear to have been affected by oxygen-depleted conditions. We carried out a bio- and chemostratigraphic study to obtain appropriate age control and correlated our results with published data from the sections of Pueblo, Colorado (GSSP for Cenomanian-Turonian boundary, Pratt and Threlkeld, 1984; Arthur et al., 1985; Kennedy et al., 2000; Keller and Pardo, 2004), Wunstorf (Voigt et al., 2008) and Eastbourne, southern England (Paul et al., 1999; Gale et al., 2005). The study of the planktonic assemblages allowed us to evaluate the eventual biotic effects in this part of the Tethyan realm. The bulk-rock mineralogy, total $\mathrm{P}$ contents and oxygen-isotope ratios record were used to trace paleoenvironmental change, and stratigraphic RSTE distributions to reconstruct fluctuations in oxygen concentration.

\section{Geological setting and lithology}

The Chrummflueschlucht section is located along a forest road northeast of Einsiedeln (Canton of Schwyz, central Switzerland; $8^{\circ} 50^{\prime} \mathrm{E}, 47^{\circ} 05^{\prime} \mathrm{N}$; Fig. 1 ). The base of the section consists of a sandy and glauconitic limestone, which corresponds to the Kamm Bed the top lithostratigraphic unit of the Garschella Formation and which is latest Albian to Middle Cenomanian in age (Fig. 2; Föllmi and Ouwehand, 1987). The remainder of the section is composed of (hemi-)pelagic carbonates of Cenomanian and Turonian age, and belongs to the Seewen Formation. The carbonate is consistently micritic and rich in calcareous dinoflagellate cysts (c-dinocysts), inoceramid prisms and planktonic foraminifera, which underlines its pelagic origin. The section measured and sampled for this study is lithostratigraphically divided into three parts. The first part is composed of mostly massive limestone beds (2-18 m; Fig. 2), which consist of wackestone rich in planktonic foraminifera and pelagic crinoid remains. The second part of the section $(18-30 \mathrm{~m}$; Fig. 2) is characterized by up to $95 \mathrm{~cm}$ thick limestone beds, which become more thinly bedded towards the top and show a transition from wackestone to packstone with smaller planktonic foraminifera at the base of this part. In the same part, we observe the occurrence of radiolaria and bryozoan debris. We also note the presence of Thalassinoides within this interval (from 18 to $23 \mathrm{~m}$ ). The last and uppermost part of the section (30 m to the top; Fig. 2) corresponds to a succession of thinly-bedded carbonates, consisting of wackestones with large planktonic foraminifera.

\section{Methods}

The biostratigraphy of the Chrummflueschlucht section is based on planktonic foraminifera, which were determined using thin sections of 102 samples in total. For the critical zones, especially for the transition of the Rotalipora cushmani to the Whiteinella archaeocretacea Zone, up to six thin-section replicates have been prepared and examined per sample. The determination of the different species was made using the systematics of Loeblich and Tappan (1988) and the Chronos website (www.chronos.org), and the planktonic zonal schemes of Robaszynski and Caron (1979, 1995).

The analysis of the bulk-rock mineralogy was carried out by X-ray diffraction (Scintag XRD 2000 Diffractometer) based on procedures described by Kübler (1983) and Adatte et al. (1996). This 


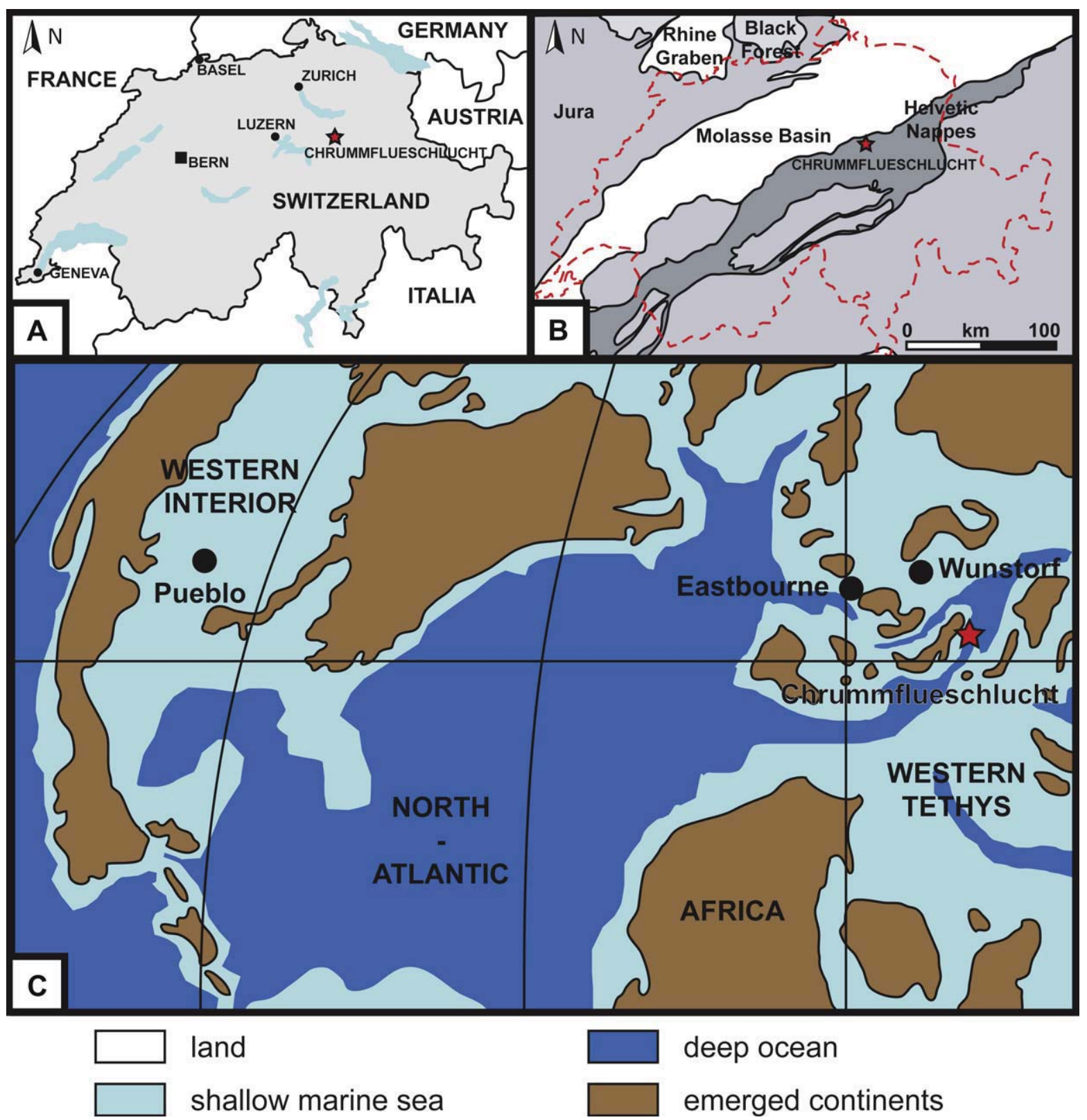

Fig. 1. A. Localisation of the Chrummflueschlucht section. B. Tectonic map of Switzerland with indication of the Helvetic realm (after Bodin et al., 2006). C. Late Cenomanian (93 Ma) paleogeographic map of the western Tethys (redrawn after Scotese et al., 2001).

semi-quantitative method is based on non-oriented powder samples with a precision of $5-10 \%$ for phyllosilicates and $5 \%$ for grain minerals. We determined a detrital index [DI $=$ Calcite $/$ (Quartz + Phyllosilicates + K-Feldspar + Na-Plagioclase)] to observe changes in detrital influx.

Carbon- and oxygen-stable isotope analyses were performed on powdered bulk-rock samples at the stable-isotope laboratory of the Universities of Orsay (Paris XI, France) and Bern (Switzerland), using VG SIRA 10 triple collector and a Finnigan Detla V Advantage mass spectrometer respectively. The results were calibrated to the PDB scale with the standard deviation of $0.05 \%$ for $\delta^{13} \mathrm{C}$ and of $0.07 \%$ for $\delta^{18} \mathrm{O}$

Total $\mathrm{P}$ analysis was performed on bulk-rock samples, following the procedure described in Bodin et al. (2006). The concentration of $\mathrm{PO}_{4}$, expressed in $\mathrm{ppm}$, is obtained by calibration with known standard solutions, using an UV/Vis photospectrometer (Perking
Elmer UV/Vis Photospectrometer Lambda $10, \lambda=865 \mathrm{~nm}$ ) with a mean precision of $5 \%$.

The determination of $\mathrm{Al}, \mathrm{Fe}$ and redox-sensitive trace elements was performed on bulk rock following the procedure described in Bodin et al. (2007). The samples were attacked by suprapur nitric acid and elements contents were determined by a quadrupole ICPMS (ELAN 6100, Perkin Elmer), using a quantitative mode with a mean precision of $1-2 \%$ depending on the element under consideration. The dissolution percentages determined after filtration were about $95 \%$ of initial sample weight in the studied section. Moreover, no correlation was observed between the concentration of the different analysed samples and the dissolution percentage obtained during the digestion procedure (Fig. 3). This shows that the studied elements are present in the soluble biogenic and authigenic phases and are not due to partial leaching of the detrital insoluble fraction. 


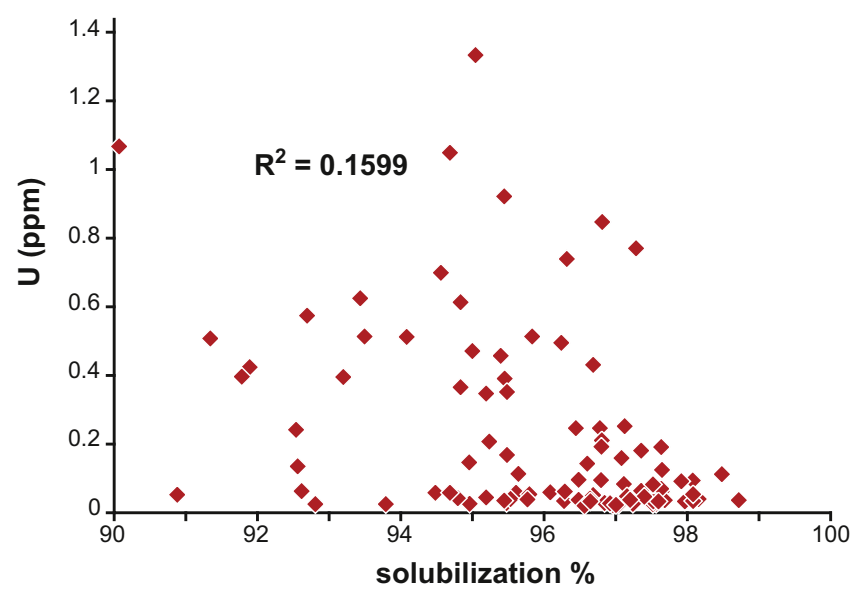

Fig. 3. $U$ contents in ppm versus the percentage of dissolution of the samples attacked by suprapur nitric acid in the section of Chrummflueschlucht.

\section{Data}

\subsection{Biostratigraphy}

The chronological framework is based on the stratigraphic distribution of planktonic foraminifera. In this study, 25 species were recognized throughout the section, including the index species of the Cenomanian-Turonian boundary interval. The stratigraphic distribution of these species is shown in Fig. 4. The three following assemblages have been distinguished based on the zonal scheme defined by Robaszynski and Caron $(1979,1995)$.

The first assemblage (the first $\sim 18 \mathrm{~m}$ of the section) is characterised by the presence of Rotalipora species, including Rotalipora reicheli, Rotalipora gandolfi, Rotalipora appenninica, Rotalipora greenhornensis, Rotalipora montsalvensis, Rotalipora brotzeni and the Upper Cenomanian index species R. cushmani. The R. cushmani Total Range Zone (TRZ) is defined by the FO of the index species situated at $7 \mathrm{~m}$ above the base of the section, just after the last occurrence (LO) of $R$. reicheli. The top of this zone is defined by the last occurrence of $R$. cushmani. The FO of Whiteinella sp., Praeglobotruncana stephani and Praeglobotruncana gibba is located near the top of the R. cushmani TRZ. The first assemblage ends with the LO of R. cushmani, at $17.9 \mathrm{~m}$, and the disappearance of Rotalipora species.

The second assemblage (from 17.9 to $31.1 \mathrm{~m}$ ) is defined by the common presence of Whiteinella species (W. archaeocretacea, Whiteinella praehelvetica, Whiteinella baltica and Whiteinella paradubica) and marked by the presence of by the common presence of double-keeled Dicarinella species (Dicarinella hagni, Dicarinella algeriana, Dicarinella canaliculata, Dicarinella imbricata), and $P$. gibba. This foraminiferal assemblage shows a change in the last three meters of this interval with the decrease in abundance of double-keeled species relative to the forms with inflated chambers. This second assemblage characterizes the $W$. archaeocretacea Partial Range Zone (PRZ) which is defined by the LO of R. cushmani and the FO of Helvetoglobotruncana helvetica. The Cenomanian-Turonian boundary is situated within this zone.

The upper part of the section characterizes the H. helvetica TRZ, which is defined by the FO of the index species $H$. helvetica (at $31.2 \mathrm{~m}$ ). This third assemblage marks the appearance of four new taxa $(H$. helvetica, Marginotruncana coronata, Marginotruncana sigali and Falsotruncana sp.) indicating an Early to Middle Turonian age.

\subsection{Stable carbon- and oxygen-isotope data}

Bulk-rock stable-isotope curves $\left(\delta^{18} \mathrm{O}\right.$ and $\left.\delta^{13} \mathrm{C}\right)$ from the Chrummflueschlucht section are plotted in Fig. 5. The $\delta^{13} \mathrm{C}$ curve shows a progressive increase in values in the first part of the section (from the base to $10 \mathrm{~m}$ ) with values ranging from 2.0 to $2.7 \%$ (VPDB). In the interval between 10 and $15.5 \mathrm{~m}, \delta^{13} \mathrm{C}$ values remain quite stable and fluctuate around $2.7 \%$. At $18 \mathrm{~m}$, the $\delta^{13} \mathrm{C}$ record shows a first relative maximum of $3.3 \%$, following the LO of $R$. cushmani. Thereafter, the $\delta^{13} \mathrm{C}$ values decrease and show two maxima at $19.3 \mathrm{~m}$ and 20.8 , respectively. After a trough between 21 and $23 \mathrm{~m}, \delta^{13} \mathrm{C}$ values increase again and arrive at a plateau (between 24 and $30 \mathrm{~m}$ ) with values of around $3.1 \%$. The plateau ends with a distinct peak at $28.8 \mathrm{~m}$. Near the top of the section, in sediments characterized by the FO $H$. helvetica zone, the $\delta^{13} \mathrm{C}$ record decreases to post-excursion values (approximately around $2.25 \%$ ). Given the planktonic foraminifera distribution, we will consider the first peak following the LO of $R$. cushmani as the onset of the positive $\delta^{13} \mathrm{C}$ excursion and the last peak before the decrease of the $\delta^{13} \mathrm{C}$ values as the end of the OAE 2 positive excursion.

The bulk-rock oxygen-isotope data record a smooth and progressive decline in $\delta^{18} \mathrm{O}$ from -2.6 to $-3.4 \%$ in the first part of the section (from the base to $12 \mathrm{~m}$ ). In the following part of the section, from 12 to $18 \mathrm{~m}$ (close to the LO of R. cushmani), the $\delta^{18} \mathrm{O}$ record shows relative stable values (around $-2.7 \%$ ) followed by a negative spike (minimum at $-3.6 \%$ ) at about $18 \mathrm{~m}$. Thereafter, $\delta^{18} \mathrm{O}$ values exhibit an increasing trend and remain quite high in the remainder of the section, with values of around $-3 \%$.

\subsection{Bulk-rock mineralogy}

At Chrummflueschlucht, the sediments consist essentially of calcite, with minor inclusions of quartz and phyllosilicates (Fig. 6). Calcite content ranges between 85 and $97 \%$ with an upwardincreasing trend. Quartz and phyllosilicates show low values, from the detection limit to $11 \%$ for quartz and to $5 \%$ for phyllosilicates, respectively. These minerals exhibit higher values in the glauconite-rich Kamm Bed (in the 2 first meters of the section). A second interval of higher quartz and phyllosilicate contents is located at $\sim 12 \mathrm{~m}$. Two further enrichments are observed in sediments at the onset of the positive $\delta^{13} \mathrm{C}$ shift (at about $15 \mathrm{~m}$ ) and below the $\delta^{13} \mathrm{C}$ plateau ( $\sim 23 \mathrm{~m}$ ), respectively. K-feldspar and Na-plagioclase occur only sporadically throughout the section.

The DI shows highest values at the onset of the $\delta^{13} \mathrm{C}$ shift and within the trough between the peaks and the plateau. DI, phyllosilicates and the unquantified minerals show similar trends, suggesting that most of the unquantifieds have a detrital origin, with a high component of phyllosilicates.

\subsection{Total phosphorus contents}

Total P contents range from 117 to 1097 ppm (Fig. 7). P-accumulation rates were not calculated because of uncertainties in the attribution of absolute ages. In the first $15 \mathrm{~m}$ of the section, in sediments attributed to the R. cushmani TRZ, P contents display small variations superimposed on a long-term decreasing trend with values reaching from $\sim 500$ to $\sim 150 \mathrm{ppm}$. In the following, the $\mathrm{P}$ trend exhibits a positive spike, reaching a maximum of $1097 \mathrm{ppm}$ in sediments representing the transition of the R. cushmani and $W$. archaeocretacea zones, coeval with the first positive peak in $\delta^{13} \mathrm{C}$. After this first peak in $\delta^{13} \mathrm{C}$, P values remain quite low, fluctuating between 150 and $200 \mathrm{ppm}$. In sediments corresponding to the end of the positive shift in $\delta^{13} \mathrm{C}$ (within the H. helvetica zone) a smooth increase is observed (290 ppm), coeval with the decrease in the $\delta^{13} \mathrm{C}$ record. 


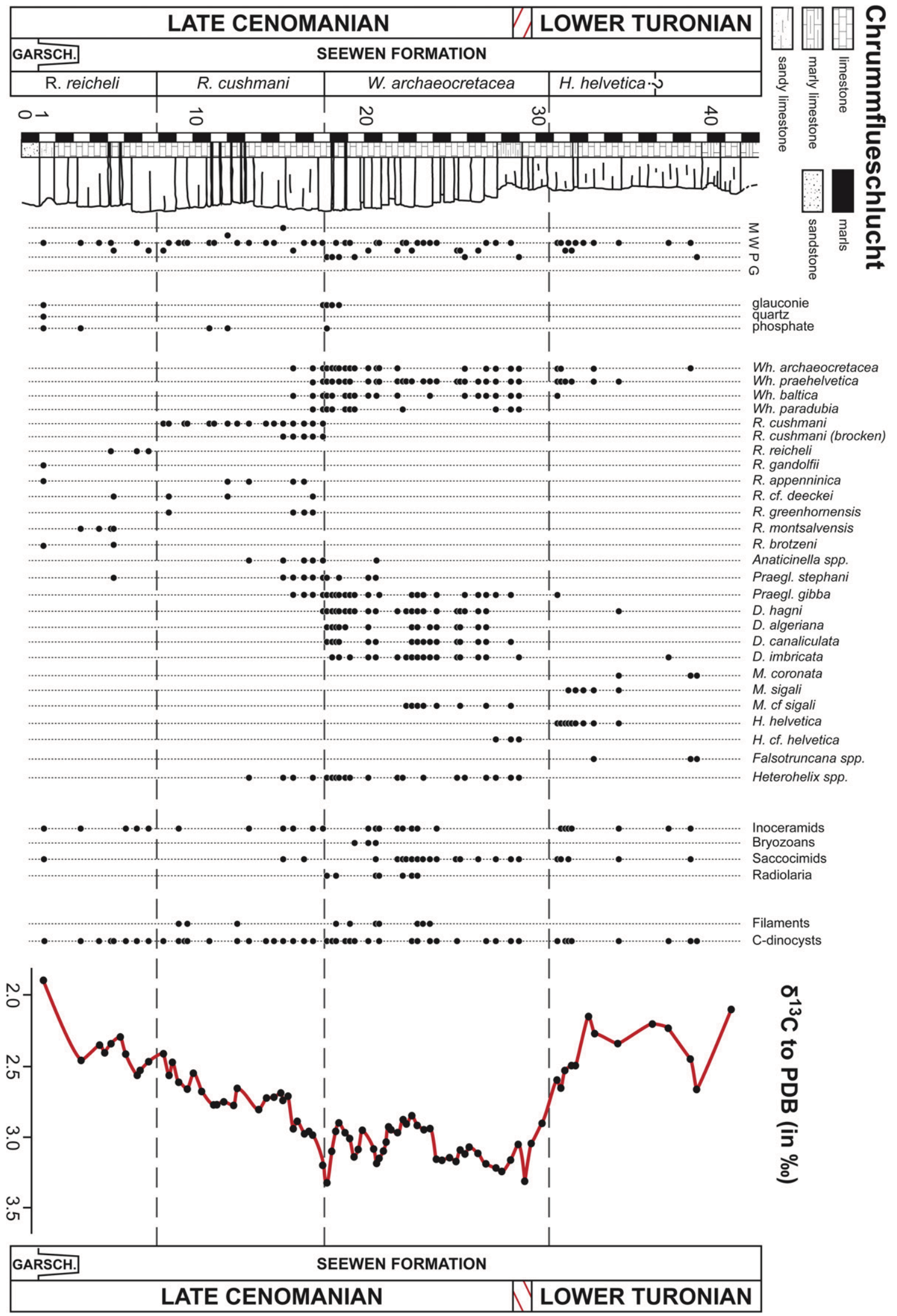

Fig. 4. Stratigraphic occurrences of planktonic and benthic foraminifera, other microfossils and macrofossil fragments. The biozonation is based on the distribution of planktonic foraminifera, the evolution of the $\delta^{13} \mathrm{C}$ curve and biostratigraphic and chemostratigraphic correlation with the Pueblo GSSP section (see text for further explanation). M, W, P, $G=$ mudstone, wackestone, packstone and grainstone. 


\section{Chrummflueschlucht}
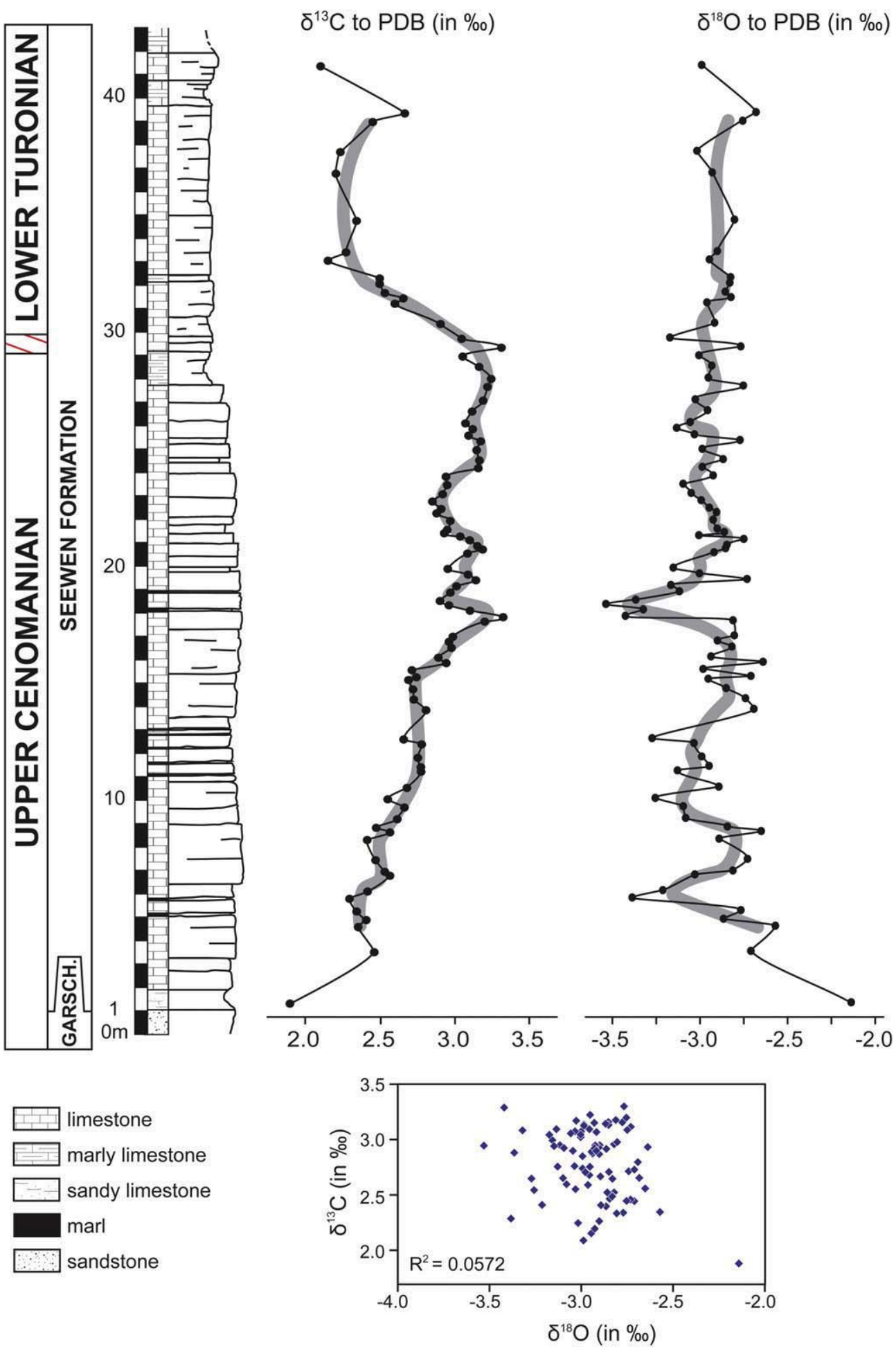

Fig. 5. $\delta^{13} \mathrm{C}$ and $\delta^{18} \mathrm{O}$ curves for the Chrummflueschlucht section. The lack of significant correlation between the $\delta^{13} \mathrm{C}$ and $\delta^{18} \mathrm{O}$ records and the absolute $\delta^{18} \mathrm{O}$ values indicate that late diagenetic processes did not affect the stable-isotope record too strongly.

\subsection{Redox-sensitive trace elements}

We investigated the stratigraphic behaviour of the following redox-sensitive trace elements: $\mathrm{U}, \mathrm{V}, \mathrm{Co}, \mathrm{Mo}, \mathrm{As}, \mathrm{Mn}$ and Fe, all of which are commonly used to interpret changes in paleoredox conditions (Algeo and Maynard, 2004; Tribovillard et al., 2006; Algeo and Lyons, 2006). The average values for U, V, As, Co and Mo correspond to approximately $0.5,2.3,0.6,2.3$ and $0.7 \mathrm{ppm}$, 


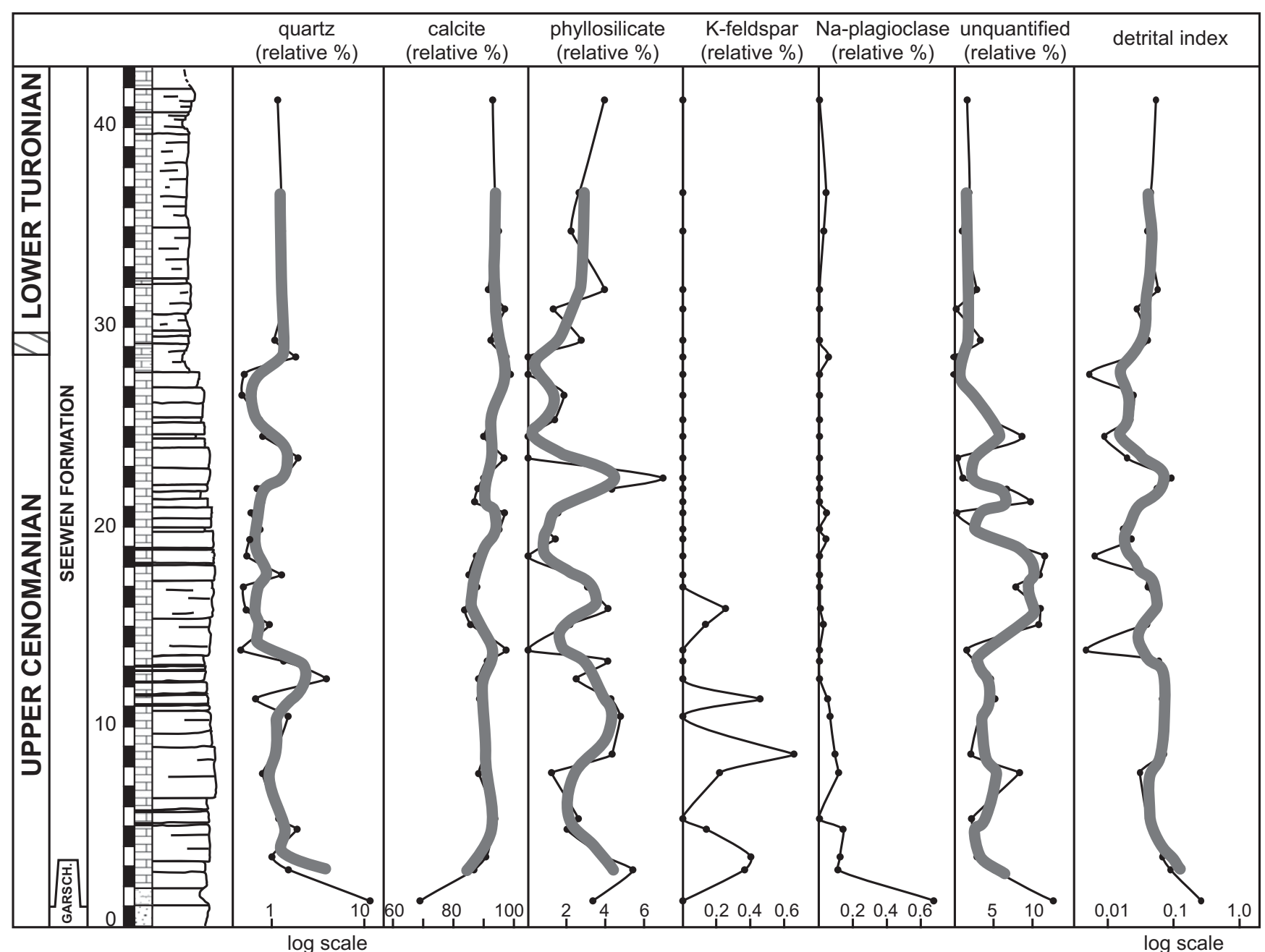

Fig. 6. Bulk-rock analysis of the Chrummflueschlucht section. Grey lines correspond to three-point average curves for the contents of quartz, calcite, phyllosilicates, unquantifieds and for the detrital index (see text). High detrital influx rates are explained by more humid climate and increased continental runoff.

respectively (Fig. 7). In the first part of the section (from the base to $12 \mathrm{~m}$ ), $\mathrm{U}$ and $\mathrm{V}$ contents show higher values ranging around 0.8 and 2.5-3 ppm, respectively. Consequently, $\mathrm{U}$ and $\mathrm{V}$ contents decrease in sediments attributed to the R. cushmani zone and remain low throughout the rest of the section, showing higher fluctuations in the first $20 \mathrm{~m}$ of the section, with values between the detection limits and $3 \mathrm{ppm}$. In the second part of the section, As shows rather low and constant values. Co displays an intermediate behaviour between $V$ and As. The lower part of the Co trend shows variations similar to As (with values between 1 and $6 \mathrm{ppm}$ ). In the second part of the section (from $20 \mathrm{~m}$ to the top), Co contents shows rather low values with a slight increase at $\sim 32 \mathrm{~m}$. Mo contents remain quite constant along the entire section and deviate towards higher values only in the interval coeval with the decrease in $\delta^{13} \mathrm{C}$ values. Mn shows values between 125 and $920 \mathrm{ppm}$. Mn concentrations exhibit a long-term decreasing trend in the first part of the section reaching a minimum of about $200 \mathrm{ppm}$ in sediments corresponding to the plateau in $\delta^{13} \mathrm{C}$. In the following, Mn values increase again to pre-OAE values. Fe shows a decreasing trend from the base of the section to the first $20 \mathrm{~m}$. Above $20 \mathrm{~m}$, Fe contents increase slightly and at $\sim 32 \mathrm{~m}$, Fe values display an increase towards $8000 \mathrm{ppm}$. Al contents are well correlated with the evolution of phyllosilicate contents, except for the interval corresponding to the $\delta^{13} \mathrm{C}$ plateau. Al contents show higher values in the first $10 \mathrm{~m}$ of the section, followed by a small decrease at $\sim 15 \mathrm{~m}$. Thereafter, Al values increase slowly and show a peak at $\sim 32 \mathrm{~m}$.

\section{Discussion}

\subsection{Stable isotopes, biostratigraphy and chronology of the OAE 2}

The reliability of $\delta^{18} \mathrm{O}$ and $\delta^{13} \mathrm{C}$ data in bulk-rock sediments is largely dependent upon the degree of diagenesis, which primarily affects oxygen-isotope values by lowering the ${ }^{18} \mathrm{O} /{ }^{16} \mathrm{O}$ ratio in sediments (e.g., Schrag et al., 1995). By cross-plotting all $\delta^{18} \mathrm{O}$ and $\delta^{13} \mathrm{C}$ values, no significant correlation has been observed for the Chrummflueschlucht section (Fig. $5, R^{2}=0.0572$ ), suggesting that late diagenetic and tectonic processes did not affect the stableisotope values too severely.

The OAE 2 is characterized by a globally recognized positive excursion in $\delta^{13} \mathrm{C}$ in both carbonate and organic matter (Schlanger and Jenkyns, 1976; Jenkyns, 1980; Pratt and Threlkeld, 1984; Gale et al., 1993; Jenkyns et al., 1994; Leckie et al., 2002; Tsikos et al., 2004; Caron et al., 2006; Jarvis et al., 2006; Grosheny et al., 2006; Voigt et al., 2006, 2007; Mort et al., 2007; Takashima et al., 2010). The typical shape of the $\mathrm{C}-\mathrm{T}$ boundary positive excursion, as observed in the GSSP section at Pueblo, Colorado (Pratt and Threlkeld, 1984; Sageman et al., 2006) and in Eastbourne, United 


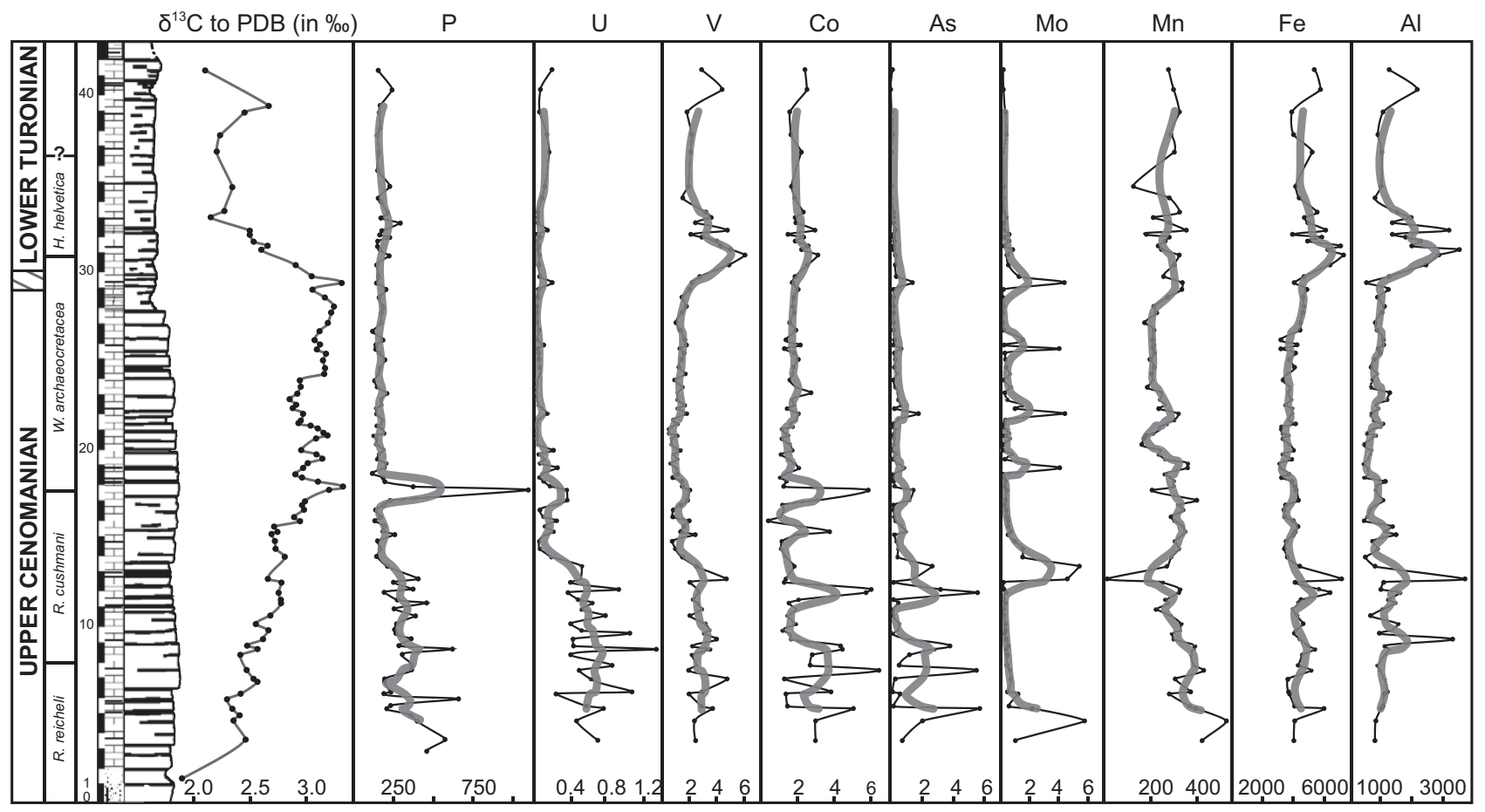

Fig. 7. Phosphorus, redox-sensitive trace elements and aluminium distributions (in ppm) for the Chrummflueschlucht section. Grey lines correspond to five-point average curves for each element.

Kingdom (Paul et al., 1999; Gale et al., 2005) is characterized by (1) a first increase in $\delta^{13} \mathrm{C}$ values (peak "a"), (2) a trough interval, (3) a second peak (peak "b") and (4) a prolonged plateau which ends with a less distinctive peak (peak "c") (Fig. 8; Jarvis et al., 2006 and references therein). In more expanded sections, four peaks are recognized (peaks A-D, Voigt et al., 2008).

In the Chrummflueschlucht section, the overall shape of the $\delta^{13} \mathrm{C}$ curve is well comparable to Pueblo and Eastbourne, however with a smaller amplitude $(\sim 1 \%)$ and a gradual increase preceding the OAE 2 excursion (Fig. 8). Peaks "a" and "c" are well recognizable; they mark the onset and the end of the C/T boundary excursion, respectively, reaching both a maximum of $\sim 3.3 \%$ (Fig. 8 ). Despite this similar trend in the $\delta^{13} \mathrm{C}$ record, the distribution of planktonic foraminifera during the OAE 2 interval shows some differences with the characteristic bio-events of $\mathrm{C} / \mathrm{T}$ boundary defined at Pueblo (Cobban and Scott, 1972; Caron et al., 2006) and Eastbourne (Paul et al., 1999; Keller et al., 2001). At Chrummflueschlucht, $R$. cushmani disappears approximately $50 \mathrm{~cm}$ below peak "a", whereas the LO of this index species is observed immediately above peak "a" at Pueblo (Keller and Pardo, 2004; Caron et al., 2006; Jarvis et al., 2006) and in the trough between peaks "a" and "b" at Eastbourne (Keller et al., 2001; Caron et al., 2006; Jarvis et al., 2006; Fig. 8). Another particularity of the Chrummflueschlucht section lies in the proximity of the LO's of $R$. greenhornensis and R. cushmani, and the FO of $D$. hagni which coincides with peak "a". This suggests the presence of a small hiatus at the onset of OAE 2 at Chrummflueschlucht. The abrupt change in microfacies observed within this interval and the relatively high proportion of glauconite and phosphatic grains in thin sections is in favour of a hiatus associated with reworked sediments. The presence of reworked sediments is frequent in the Seewen formation for this time interval (Föllmi and Ouwehand, 1987; Föllmi, 1989). This may imply that the first peak in the $\delta^{13} \mathrm{C}$ record at Chrummflueschlucht does not represent the whole peak "a" but rather a combination of the onset and the end of the peak observed at Pueblo or Eastbourne (Fig. 8).
The determination of peak " $b$ " is more questionable. In the sections of Pueblo, Eastbourne and Wunstrof, peak "b" is coeval with the "Heterohelix shift" (Leckie, 1985; Leckie et al., 1991, 1998; Nederbragt and Fiorentino, 1999; Huber et al., 1999; Caron et al., 2006; Jarvis et al., 2006). This event follows the disappearance of complex keeled morphotypes. At Chrummflueschlucht, two peaks of similar amplitude follow peak "a" but no change in the distribution of Heterohelicids has been observed along the section. It is therefore difficult to discriminate which of these two peaks corresponds to peak "b". In any case, the coincidence of the LO of Anaticinella ssp. with the last peak of these two maxima (at $20.8 \mathrm{~m}$ ), indicates that we are still in the Cenomanian.

The following plateau in stable carbon-isotope values is comparable to the plateau in the Pueblo section, suggesting that the Chrummflueschlucht preserves a relatively complete succession of the Cenomanian-Turonian boundary. The Lower Turonian FO of $H$. helvetica is observed in an interval following peak "c" (Fig. 8), during the subsequent negative excursion in the $\delta^{13} \mathrm{C}$ record, which marks the end of the OAE 2 excursion, in analogy to Pueblo (Keller and Pardo, 2004; Caron et al., 2006; Desmares et al., 2007).

The similarity in the $\delta^{13} \mathrm{C}$ excursions between the Chrummflueschlucht and Pueblo sections, with as only deviation a probable merger of a part of peak "a", shows that the Chrummflueschlucht section records a large part of OAE $2 \delta^{13} \mathrm{C}$ positive excursion. It also indicates that the Chrummflueschlucht section constitutes one of the most complete sections in the Helvetic thrust-and-fold belt for the Upper Cenomanian-Lower Turonian known so far.

\subsection{Planktonic foraminifera as environmental proxies}

The microfossil assemblages through the Cenomanian-Turonian boundary interval show distinct differences in their morphologies through time, which are related to different ecological conditions (Caron and Homewood, 1982; Hart and Bailey, 1979; Hart, 1980). A first group consists of K-selected species 


\section{OAE 2 C-isotopic shift}

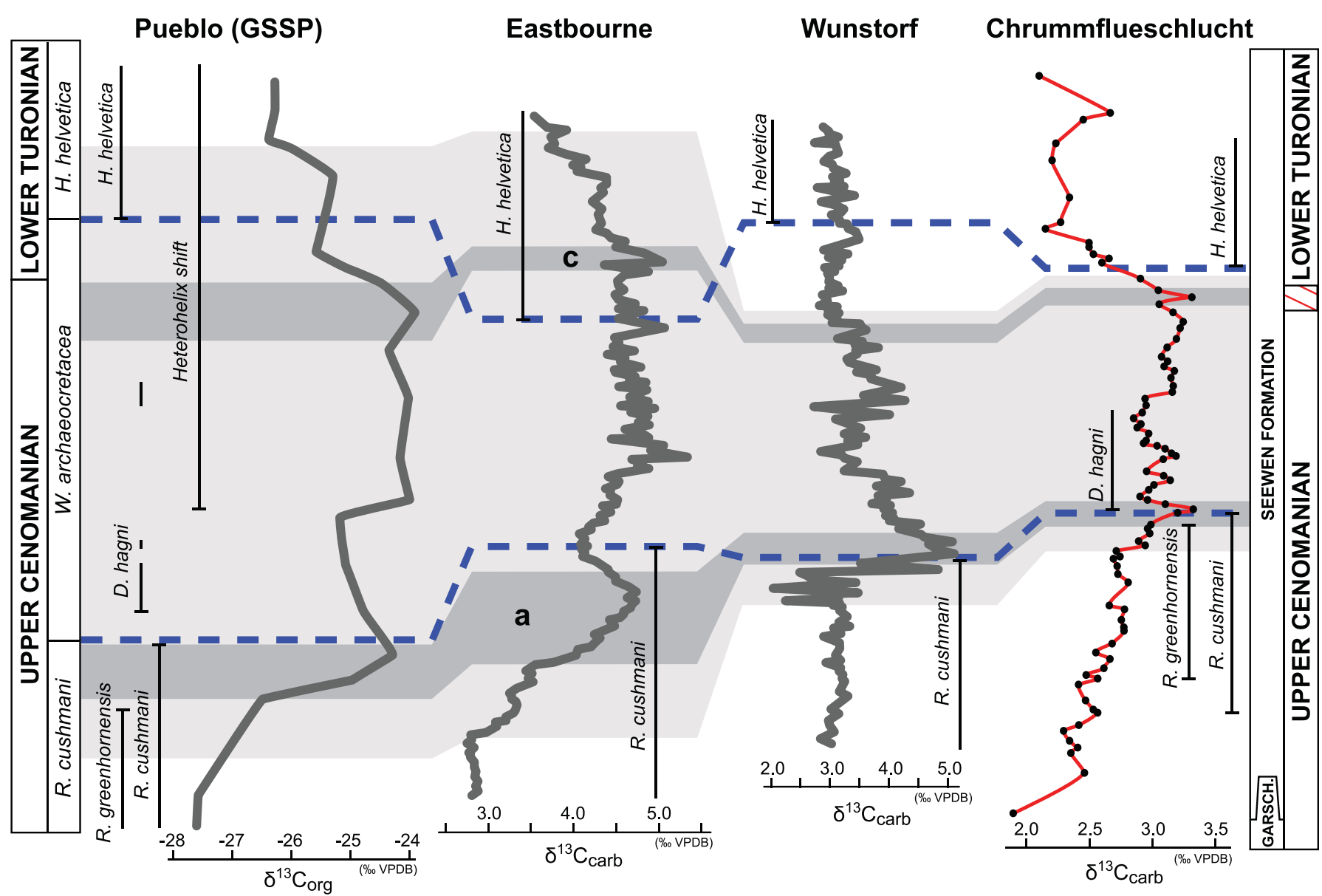

Fig. 8. Stratigraphic correlations for the end-Cenomanian OAE 2 (light grey) between the sections of Chrummflueschlucht, Pueblo $\left(\delta^{13} \mathrm{C}_{\text {org, }}\right.$ after Pratt and Threlkeld, 1984 ; planktonic foraminifera distribution after Keller and Pardo, 2004), Eastbourne (Paul et al., 1999) and Wunstorf (Voigt et al., 2008). The dark grey bands indicate the position of the peaks "a" and "c".

(MacArthur and Wilson, 1967), which characterize large trochospiral, keeled, forms with complex morphotypes and inferred long reproduction cycles (Caron, 1983; Grosheny and Malartre, 1997; Keller et al., 2001; Caron et al., 2006; Robaszsynski et al., 2010). They dominate the planktonic assemblages from the $R$. cushmani and the $H$. helvetica TRZ, which are periods characterized by welloxygenated water with low nutrient levels allowing a specific diversification and the development of more sophisticated morphotypes (Grosheny and Malartre, 1997; Caron et al., 2006; Mort et al., 2007). The second group is composed of globular trochospiral and biserial forms with small and simple morphotypes (e.g., Whiteinella and Heterohelix), which mainly lived in the upper-water column with high nutrient levels (Hart and Leary, 1989; Petters, 1980; Jarvis et al., 1988; Grosheny and Malartre, 1997; Leckie et al., 1998; Keller and Pardo, 2004). They are interpreted as r-selected species (MacArthur and Wilson, 1967) and date from the W. archaeocretacea PRZ.

The global disappearance of complex K-selected forms with long reproduction cycles (rotaliporoids) at the onset of OAE 2 has been explained by the development of oxygen-depleted conditions in the deeper part of the water column (Leckie, 1987; Leckie et al., 1998; Keller and Pardo, 2004; Caron et al., 2006). This change in the morphology of planktonic foraminifera is also observed in the Chrummflueschlucht section. At Chrummflueschlucht, however, the planktonic assemblage attributed to the $W$. archaeocretacea PRZ is dominated by large morphotypes of the double-keeled genera Dicarinella and Praeglobotruncana. The planktonic foraminifera turnover characterizing the $\mathrm{C} / \mathrm{T}$ boundary in this part of the Tethys is, therefore, atypical compared to other oceanic settings. This is interpreted as relatively favourable conditions in the Helvetic pelagic realm during OAE 2.

The same morphotypes have also been observed at the wadi Bahloul section, Tunisia, and their episodic appearance during the Late Cenomanian part of the $W$. archaeocretacea PRZ has been interpreted as the result of the episodic return to less stressful conditions (Caron et al., 2006).

Only near the end of the $W$. archaeocretacea PRZ, a strong diminution in Dicarinella and Praeglobotruncana species and a dominance of Whiteinella is observed. Since sedimentological and geochemical indications for oxygen-depleted conditions are missing for this particular part of the section (see below), this shift towards r-selected species is probably a reflection of global rather than regional conditions.

\subsection{Paleoenvironmental conditions in the Helvetic realm during OAE 2}

The bulk-rock mineralogical composition and especially the detrital index (DI) provide valuable information on environmental and climatic change. Low DI values indicate higher continental 
runoff, and vice versa. In the Chrummflueschlucht section, the interval corresponding to the positive $\delta^{13} \mathrm{C}$ excursion is marked by an increase in detrital influx (low DI values). This interval is also characterized by a positive correlation of the stratigraphic trends in $\mathrm{DI}, \mathrm{P}$ and $\mathrm{Al}$ contents, suggests a coupling between runoff and $\mathrm{P}$ delivery. The lower DI and higher P values may indicate higher nutrient levels during this time interval. The increase in P contents has been observed in other sections of the Tethys and the North Atlantic indicating a change in continental runoff and nutrient influx and/or intensification in upwelling during the Late Cenomanian (Mort et al., 2007). This inferred change in nutrient input may have triggered an increase in primary productivity and a concomitant increase in $\delta^{13} \mathrm{C}$ values (Ingall et al., 1993; Van Cappellen and Ingall, 1994; Föllmi, 1995; Mort et al., 2007). Organic-rich sediments are, however, lacking in the Chrummflueschlucht section. Black shales related to OAE 2 have been found in the Ultrahelvetic Zone (Strasser et al., 2001; Wagreich et al., 2008) indicating increased organic-matter production and/or better preservation in deeper, distal parts of the northern Tethyan shelf.

Following the first maximum in the $\delta^{13} \mathrm{C}$ curve, $\mathrm{P}$ contents are less well correlated with $\mathrm{Al}$ contents and $\mathrm{DI}$ variations: Al values increase and DI values generally decrease in sediments attributed to the $W$. archaeocretacea zone, whereas $P$ contents remain low. This has also been observed in other sections and has been attributed to the decreased retention capacity of $\mathrm{P}$ in sediments during OAE 2 (Mort et al., 2007). Of interest is the observation that the same trend is observed in sections submitted to different degrees of oxygen depletion during OAE 2 . The fact that this trend is also observed in Chrummflueschlucht, despite the obvious lack of anoxia during OAE 2, is an indication that the diminution in $\mathrm{P}$ burial rates is a global phenomenon (cf. Föllmi, 1995).
Changes in detrital influx are partly associated with high values in the $\delta^{18} \mathrm{O}$ record. The observed pattern in oxygen stable-isotopes recorded at Chrummflueschlucht is comparable to the published curves of the sections at Eastbourne and Gubbio (Jenkyns et al., 1994; Tsikos et al., 2004) and also with the section of Rehkogelgraben in the Ultrahelvetic unit (Wagreich et al., 2008). Oxygen stable isotopes in carbonates are more affected by diagenesis compared to carbon isotopes (Schrag et al., 1995), but the good agreement between Chrummflueschlucht and other sections of the northern Tethys indicates that the long-term variations in the $\delta^{18} \mathrm{O}$ signal represent a consistent trend (Fig. 9). However, the magnitude of the temperature change based on bulk-rock oxygen-isotopes is difficult to constrain because of the diagenetic alteration of fossil carbonate (Gale and Christensen, 1996; Wilson et al., 2002; Voigt et al., 2004) and the uncertainty with regards to the isotopic composition of the Cretaceous seawater (Wilson et al., 2002; Keller and Pardo, 2004; Voigt et al., 2004; Kuhn et al., 2005). The Cenomanian-Turonian transition corresponds to the onset of the interval of peak Cretaceous warmth, which reached its thermal maximum in the Late Turonian (Clarke and Jenkyns, 1999; Wilson et al., 2002). The decreasing trend in $\delta^{18} \mathrm{O}$ values before the onset of the OAE 2 is consistent with a warmer climate associated with higher rates in continental runoff. During OAE 2, a brief cooling episode is recognized based on southward migrations of boreal fauna (Jefferies, 1962; Jenkyns et al., 1994; Gale and Christensen, 1996), on oxygen-isotope records and TEX 86 data (Norris et al., 2002; Wilson et al., 2002; Voigt et al., 2004; Forster et al., 2007; Sinninghe Damsté et al., 2010). At Chrummflueschlucht, the small plateau of higher oxygen-isotope values at the onset of OAE 2 (peak "a") may relate to this cooling episode. An alternative explanation consists in an input of fresh water at the onset of the shift (Sageman et al., 1998; Keller et al., 2008). At Chrummflueschlucht, the good

\section{Eastbourne, England}

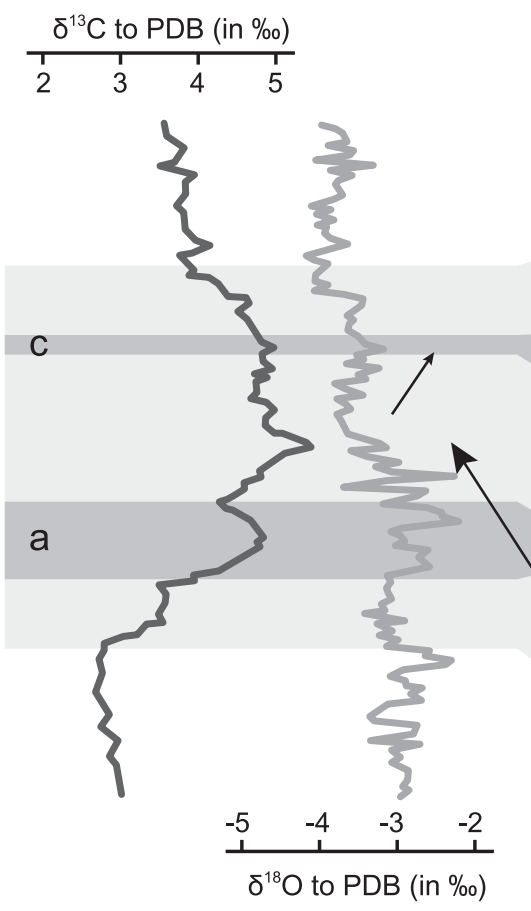

\section{Rehkogelgraben, Austria}

\section{Chrummflueschlucht, Switzerland}

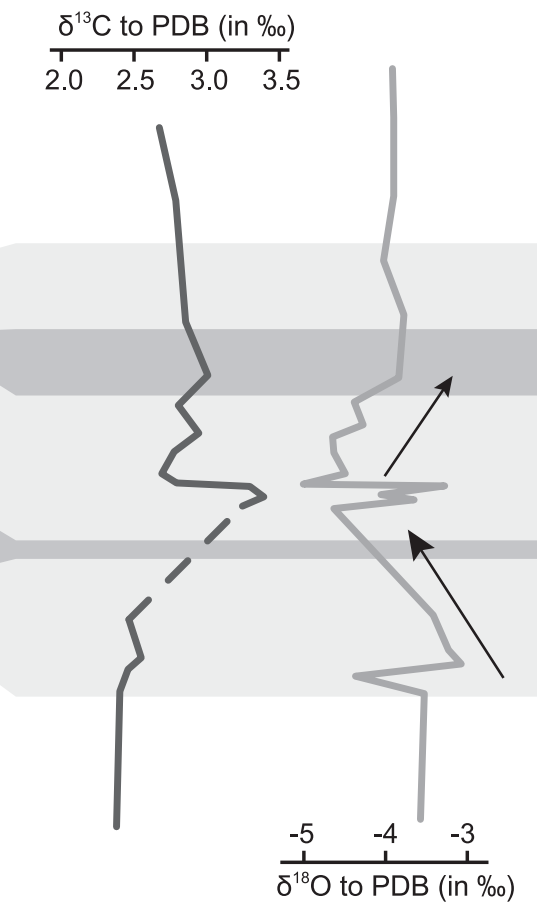

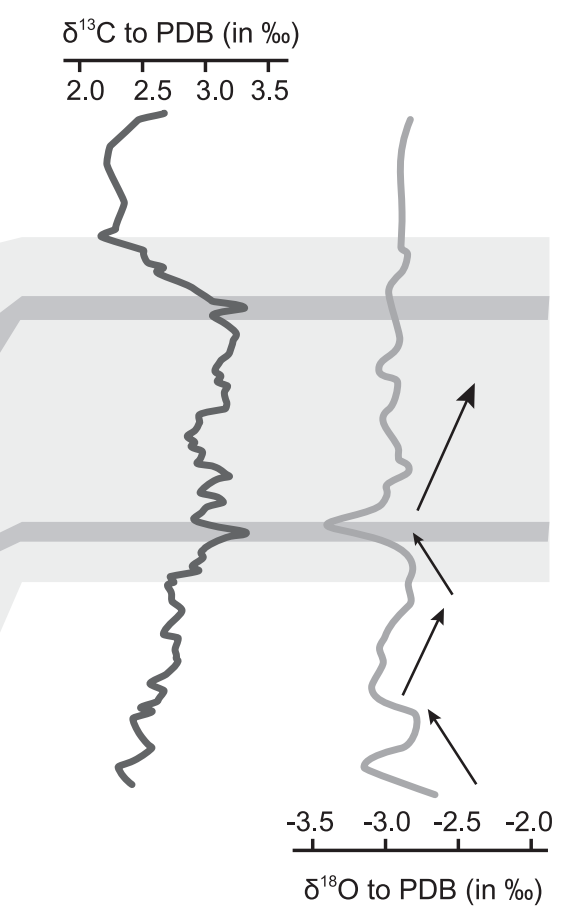

Fig. 9. Change in $\delta^{18} \mathrm{O}$ through the end-Cenomanian OAE 2 in the sections of Eastbourne (Tsikos et al., 2004), Rehkogelgraben (Wagreich et al., 2008) and Chrummflueschlucht. Dark grey bands indicate the position of the Peaks 1 and 2. 


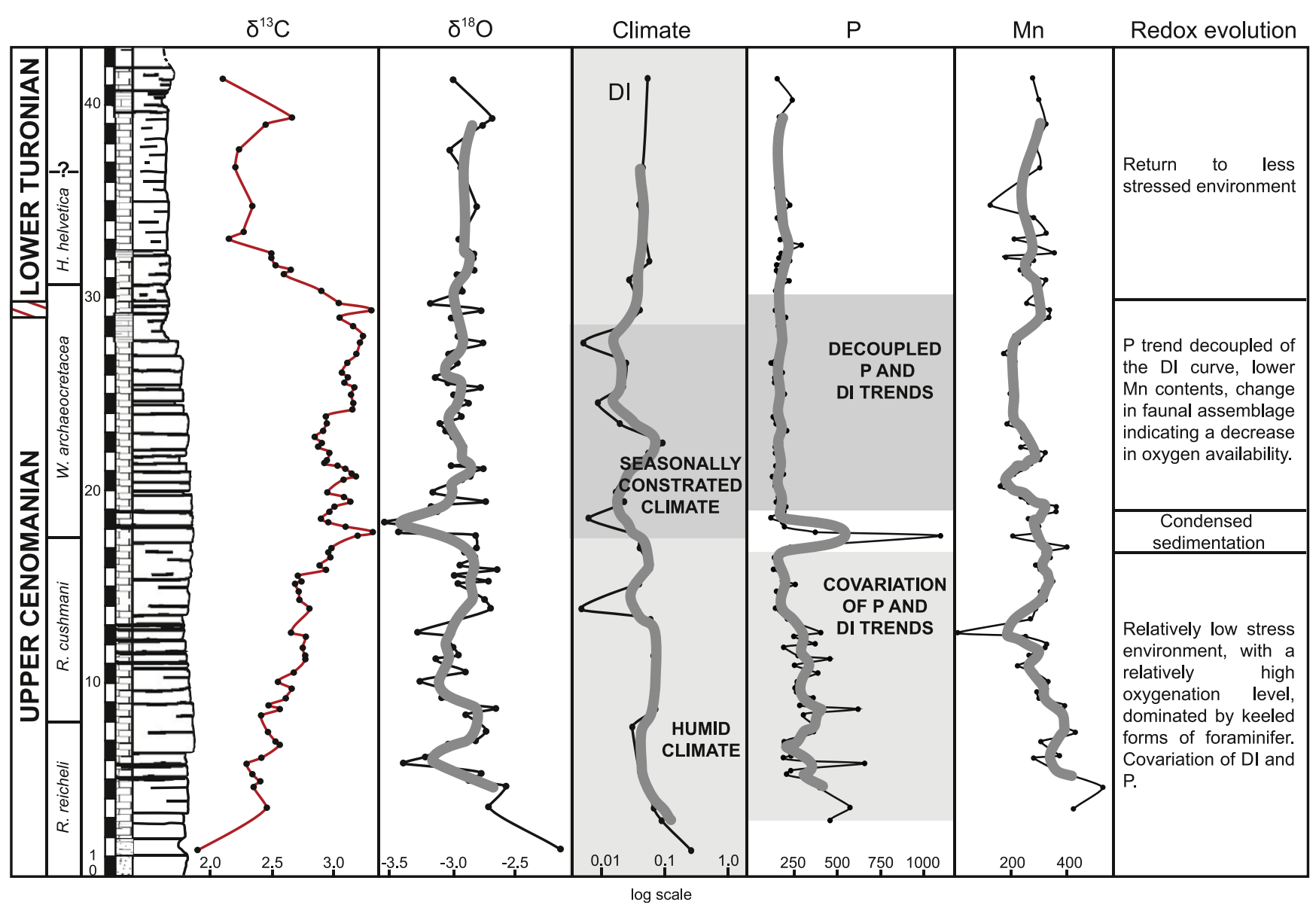

Fig. 10. Summary of paleoenvironmental proxies including $\delta^{13} \mathrm{C}$ and $\delta^{18} \mathrm{O}$ (in \% to PDB), climate change (as deducted from the stratigraphic trends in the mineralogy and $\mathrm{P}$ contents) and redox variations (from faunal assemblage and TM contents) across OAE 2 in the Helvetic realm.

correlation between trends in the DI and $\delta^{18} \mathrm{O}$ records goes along with a paleoclimatic interpretation of the latter record. A negative spike in $\delta^{18} \mathrm{O}$ values follows the onset of the positive $\delta^{13} \mathrm{C}$ excursion. This may be linked to a return to warmer and more humid climate (Fig. 10). The second part of the positive shift shows an increasing trend in the $\delta^{18} \mathrm{O}$ record, which is associated with low detrital input. Contrary to other places where a general warming is observed (Jenkyns et al., 1994; Norris et al., 2002; Wilson et al., 2002; Voigt et al., 2004; Forster et al., 2007; Sinninghe Damsté et al., 2010), at Chrummflueschlucht, the evolution of the $\delta^{18} \mathrm{O}$ record suggests a change in the regional hydrological cycle related to a possible cooling and more contrasted climate or more arid period (Keller et al., 2008).

\subsection{Redox conditions in the Helvetic realm during OAE 2}

The behaviour of $\mathrm{P}$ in relation to the change in planktonic foraminiferal assemblages suggests a change towards oxygendepleted conditions in the western Tethys. Mort et al. (2007) suggested a direct dependency between the evolution of redox conditions and P-accumulation rates during OAE2, with lowered $P$ retention rates during dysoxic/anoxic conditions. The higher $\mathrm{P}$ contents in sediments at the onset of the $\delta^{13} \mathrm{C}$ positive excursion, followed by lower P values during the $\delta^{13} \mathrm{C}$ excursion decoupled from detrital proxies are in good agreement with this hypothesis.

Mn contents show a long-term decrease, which may be in favour of oxygen-depleted conditions. Mn is generally not used as a paleoredox proxy due to its high mobility in reducing sediments
(Tribovillard et al., 2006). However, a negative correlation is frequently observed between Mn trapping and the development of anoxic conditions (Frakes and Bolton, 1992; Brumsack, 1986; Kuhn et al., 2005; Tribovillard et al., 2006). At Chrummflueschlucht, the positive shift in $\delta^{13} \mathrm{C}$ is coeval with a decrease in Mn contents. This, together with the decoupling of the trends in the contents of $\mathrm{P}$ and detrital proxies may indicate the beginning of oxygen depletion in the water column. In the Pueblo section, enrichments in Co and Mo indicate strong oxygen depletion in the Western Interior Seaway (Snow et al., 2005). However, the suite of RSTE (U, V, Mo, Co, As) shows no correlative enrichments along the section of Chrummflueschlucht (Fig. 7). The higher values of $U$ corresponds to higher values in $\mathrm{DI}$, and the trend in $\mathrm{V}$ contents is similar to the Al trend indicating that these RSTE enrichments are principally of detrital origin. This provides evidence for the absence of well-developed anoxic conditions at this site of the Helvetic realm (Tribovillard et al., 2006). However, one has to bear in mind that the onset of the $\delta^{13} \mathrm{C}$ positive shift may be related to a possible reduction in sediment accumulation in the Chrummflueschlucht section, which as such may represent a loss of information on the time period directly after the onset of OAE2. The presence of Dicarinella and Praeglobotruncana during most of the $\delta^{13} \mathrm{C}$ positive excursion is another argument against full-fletched anoxic conditions.

\section{Depositional model and conclusions}

The Chrummflueschlucht section provides a good opportunity to reconstruct the effects of the Cenomanian-Turonian Boundary 
Event in the pelagic environment of the Helvetic realm. The positive $\delta^{13} \mathrm{C}$ excursion and the accompanying characteristic overturn in planktonic foraminifera are documented in high detail.

The presence of keeled foraminifera and the moderate P and detrital contents indicate a relatively low stress environment during the $R$. reicheli Zone and most of the $R$. cushmani Zone. At the onset of the $\delta^{13} \mathrm{C}$ positive excursion near the limit between the $R$. cushmani and the $W$. archaeocretacea Zones, the P record shows a rapid spike linked to the presence of glauconitic and phosphatic grains. This probably corresponds to a small slowdown or a stop in the sedimentation, which may have been linked to the end-Cenomanian sea-level rise (Haq et al., 1987), and results in an early disappearance of $R$. cushmani in comparison to the Pueblo GSSP section.

At the base of the $W$. archaeocretacea PRZ, the positive $\delta^{13} \mathrm{C}$ excursion coincides with the disappearance of single-keeled species, low $\mathrm{P}$ contents decoupled from detrital input and a decrease in Mn contents. This may reflect increasing dysaerobic conditions and an increasingly stressed environment. However, the absence of organic-rich sediments and obvious RSTE enrichments, and the abundance of doubled-keeled species during the lower part of the OAE 2 interval suggest that full-fletched anoxic conditions did not develop in the pelagic zone of the northern Tethyan margin. The end of the $\delta^{13} \mathrm{C}$ positive excursion is marked by the reappearance of single- and double-keeled forms ( $H$. helvetica TRZ).

The pelagic character of the section and the dominance of planktonic foraminifera along the section indicate that the section was situated in the deeper part of the shelf. The chemical redox proxies place the section, however, well above the core of the oxygen-minimum zone (OMZ), which probably fluctuated and expanded onto the shelf during OAE 2. The paleoecological and geochemical proxies observed at Chrummflueschlucht suggest that anoxic conditions never reached the Helvetic pelagic part of the northern Tethyan, southern European margin.

\section{Acknowledgments}

We would like to thank Stéphane Bodin for his their help in the field, Tiffany Monnier for laboratory assistance and André Villard for the preparation of thin sections. We also thank Haydon Mort for advise on the phosphorus analysis and for his general comments and suggestions. We acknowledge D. Grosheny (Strasbourg) and F. Wiese (Berlin) for their reviews and their constructive comments. This research is supported by the Swiss National Science Foundation (Grants 200021-109514/1 and 200020-113640).

\section{References}

Adams, D.D., Hurtgen, M.T., Sageman, B.B., 2010. Volcanic triggering of a biogeochemical cascade during oceanic anoxic event 2. Nature Geoscience 3, 201-204. Adatte, T., Stinnesbeck, W., Keller, G., 1996. Lithostratigraphic and mineralogic correlations of near K/T boundary sediments in northeastern Mexico: implications for origin and nature deposition. In: Ryder, G., Fastovsky, D., Gartner, S. (Eds.), The Cretaceous-Tertiary Event and Other Catastrophes in Earth History. Boulder, Colorado, Geological Society of America Special Paper, vol. 307, pp. $211-226$.

Algeo, T.J., Lyons, T., 2006. Mo-total organic carbon covariation in modern anoxic marine environments: implications for analysis of paleoredox and paleohydrographic conditions. Paleoceanography 21. doi:10.1029/2004PA001112.

Algeo, T.J., Maynard, J.B., 2004. Trace-element behaviour and redox facies in core shales of Upper Pennsylvanian Kansas-type cyclothems. Chemical Geology 206, 289-318.

Algeo, T.J., Maynard, J.B., 2008. Trace metal covariation as a guide to water-mass conditions in ancient anoxic marine environments. Geosphere 4, 872-887. doi:10.1130/GES00174.1.

Arthur, M.A., Schlanger, S.O., 1979. Cretaceous oceanic anoxic events as causal factors in development of reef-reservoired giant oil fields. American Association of Petroleum Geologists Bulletin 63, 870-885.

Arthur, M.A., Dean, W.E., Pollastro, R.M., Claypool, G.E., Scholle, P.A., 1985. Comparative geochemical and mineralogical studies of two cyclic transgressive pelagic limestone units, Cretaceous Western Interior Basin, U.S. In: Pratt, L.M.,
Kauffman, E.G., Zelt, F.B. (Eds.), Fine-grained Deposits of Cyclic Sedimentary Processes. Society of Economic Paleontologists and Mineralogists Guidebook 4, $16-27$.

Bodin, S., Godet, A., Föllmi, K.B., Vermeulen, J., Arnaud, H., Strasser, A., Fiet, N., Adatte, T., 2006. The late Hauterivian Faraoni oceanic anoxic event in the western Tethys: evidence from phosphorus burial rates. Palaeogeography, Palaeoclimatology, Palaeoecology 235, 245-264.

Bodin, S., Godet, A., Matera, V., Steinmann, P., Vermeulen, J., Gardin, S., Adatte, T., Coccioni, R., Föllmi, K.B., 2007. Enrichment of redox-sensitive trace metals (U, V, Mo, As) associated with the late Hauterivian Faraoni oceanic anoxic event. International Journal of Earth Sciences 96, 327-341. doi:10.1007/s00531-0060091-9.

Bolli, H., 1944. Zur Stratigraphie der Oberen Kreide in den höheren helvetischen Decken. Eclogae geologicae helvetiae 37 (2), 218-328.

Brumsack, H.-J., 1986. The inorganic geochemistry of Cretaceous black shales (DSDP Leg 41) in comparison to modern upwelling sediments from the Gulf of California. In: Geological Society, London, Special Publication, vol. 21 447-462.

Brumsack, H.-J., 2006. The trace metal content of recent organic carbon-rich sediments: implications for Cretaceous black shales formation. Palaeogeography, Palaeoclimatology, Palaeoecology 232, 344-361.

Bralower, T.J., Thierstein, H.R., 1984. Low productivity and slow deep-water circulation in mid-Cretaceous oceans. Geology 12, 614-618.

Caron, M., 1983. La spéciation chez les foraminifères planctiques: une réponse adaptée aux contraintes de l'environnement. Zitteliana 10, 671-676.

Caron, M., Homewood, P., 1982. Evolution of early planktonic foraminifers. Marine Micropaleontology 7, 453-462.

Caron, M., Dall'Agnolo, S., Accarie, H., Barrera, E., Kauffman, E.G., Amédro, F., Robaszynski, F., 2006. High-resolution stratigraphy of the Cenomanian-Turonian boundary interval at Pueblo (USA) and wadi Balhoul (Tunisia): stable isotope and bio-events correlation. Geobios 39, 171-200.

Clarke, L.J., Jenkyns, H.C., 1999. New oxygen isotope evidence for lon-term Cretaceous climatic change in the Southern Hemisphere. Geology 27, 699-702.

Cobban, W.A., Scott, G.R., 1972. Stratigraphy and ammonite fauna of the Graneros Shale and Greenhorn Limestone near Pueblo, Colorado. United States Geological Survey, Professional Paper 645, 108 pp.

Delamette, M. 1988. L'evolution du domaine helvétique (entre Bauges et Morcles) de l'Aptien supérieur au Turonien: series condensées, phosphorites et circulations océaniques. Publicatio du Départemtn de la géologie et paleontology, Université Genève. 5,316pp.

Desmares, D., Grosheny, D., Beaudoin, B., Gardin, S., Gauthier-Lafaye, F., 2007. High resolution stratigraphic record constrained by volcanic ash beds at the CenomanianeTuronian boundary in the Western Interior Basin, USA. Cretaceous Research 28, 561-582.

Eicher, D.L., Worstell, P., 1970. Cenomanian and Turonian foraminifera from the Great Plains, United States. Micropaleontology 16, 269-324.

Erba, E., 2004. Calcareous nannofossils and Mesozoic oceanic anoxic events. Marine Micropaleontology 52, 85-106.

Erbacher, J., Thurow, J., Littke, R., 1996. Evolution patterns of radiolaria and organic matter variations: a new approach to identify sea-level changes in mid-Cretaceous pelagic environments. Geology 24, 499-502.

Föllmi, K.B., 1995. 160 m.y. record of marine sedimentary phosphorus burial: coupling of climate and continental weathering under greenhouse and icehouse conditions. Lecture Notes in Earth Sciences, Springer-Verlag 23, 153.

Föllmi, K.B., 1989. Evolution of the mid-Cretaceous Triad. Geology 23, 859-862.

Föllmi, K.B., Ouwehand, P.J., 1987. Garschalla-Formation und Götzis-Schichten (Aptian-Coniacian): Neue stratigraphische Daten aus dem Helvetikum der Ostschweiz und des Vorarlbergs. Eclogae geologicae Helvetiae 80, 141-191.

Forster, A., Schouten, S., Moriya, K., Wilson, P.A., Sinninghe Damsté, J.S., 2007. Tropical warming and intermittent cooling during the Cenomanian/Turonian oceanic anoxic event 2: sea surface temperature records from the equatorial Atlantic. Paleoceanography 22, PA1219. doi:10.1029/2006PA001349.

Frakes, L., Bolton, B., 1992. Effects of ocean chemistry, sea level, and climate on the formation of primary manganese ore deposits. Economic Geology 87, 1207-1217. doi:10.2113/gsecongeo.87.5.1207.

Gale, A.S., Jenkyns, H.C., Kennedy, W.J., Corfield, R.M., 1993. Chemostratigraphy versus biostratigraphy: data from around the Cenomanian-Turonian boundary. Journal of the Geological Society of London 150, 29-32.

Gale, A.S., Christensen, W.K., 1996. Occurrence of the belemnite Actinocamax plenus in the Cenomanian of SE France and its significance. Bulletin of the Geological Society of Denmark 43 (1996), pp. 68-77.

Gale, A.S., Kennedy, W.J., Voigt, S., Walaszczyk, I., 2005. Stratigraphy of the Upper Cenomanian-Lower Turonian Chalk succession at Eastbourne, Sussex, UK: ammonites, inoceramid bivalves and stable carbon isotopes. Cretaceous Research 26, 460-487.

Grosheny, D., Malartre, F., 1997. Stratégies adaptatives des foraminifères benthiques et planctoniques à la limite Cénomanien-Turonien dans le basin du S.E de la France: essai de compréhension globale. Geobios 21, 181-193.

Grosheny, D., Beaudoin, B., Morel, L., Desmares, D., 2006. High-resolution biotratigraphy and chemostratigraphy of the Cenomanian/Turonian boundary event in the Vocontian Basin, southeast France. Cretaceous Research 27, 629-640.

Haq, B.U., Hardenbol, J., Vail, P.R., 1987. Chronology of fluctuating sea levels since the Triassic. Science 235, 1156-1166.

Hardas, P., Mutterlose, J., 2007. Calcareous nannofossil assemblages of Oceanic Anoxic Event 2 in the equatorial Atlantic: evidence of an eutrophication event. Marine Micropaleontology 66, 52-69. 
Hart, M.B., 1980. A water depth model for the evolution of the planktonic foraminifera. Nature 286, 252-254.

Hart, M.B., Ball, K.C. 1986. Late Cretaceous anoxic events, sea-level changes and the evolution of the planktonic foraminifera. In: Summerhayes, C.P., Shackleton, N.J. (Eds.), North Atlantic Palaeoceanography. Geological Society of America, Special Publication, vol. 21, pp. 67-78.

Hart, M.C., Bailey, H.W., 1979. The distribution of planktonic foraminiferida in the Mid-Cretaceous of NW Europe. In: Wiedmann, J. (Ed.), Aspekte der Kreide Europas. International Union of Geological Sciences, vol. 6, pp. 527-542.

Hart, M.B., Bigg, P.C., 1981. Anoxic events in the Late Cretaceous chalk seas of northwest Europe. In: Neale, J., Brasier, M.D. (Eds.), Microfossil from Recent and Fossil Shelf Seas. British Micropalaeontological Society, Special Publication. Ellis Horwood, Chichester, pp. 177-185.

Hart, M.B., Leary, P.N., 1989. The stratigraphic and palaeogeographic setting of the late Cenomanian "anoxic" event. Journal of the Geological Society of London 146, 252-254. doi:10.1038/286252a0.

Huber, B.T., Bralower, T.J., Leckie, R.M., 1999. Paleoecological and geochemical signatures of Cretaceous anoxic events: a tribute to William V. Sliter. Journal of Foraminiferal Research 29, 313-506.

Huber, B.T., Norris, R.D., McLeod, K.G., 2002. Deep-sea paleotemperature record of extreme warmth during the Cretaceous. Geology 30, 123-126. doi:10.1130/ 0091-7613(2002)030|0123:DSPROE $\mid 2.0 . C O ; 2$.

Ingall, E.D., Van Cappellen, P., 1990. Relation between sedimentation rate and burial of organic phosphorus and organic carbon in marine sediments. Geochimica et Cosmochimica Acta 54, 373-386.

Ingall, E.D., Bustin, R.M., Van Cappellen, P., 1993. Influence of water column anoxia on the burial and preservation of carbon and phosphorus in marine shales. Geochimica et Cosmochimica Acta 57, 303-316.

Jarvis, I., Carson, G.A., Cooper, M.K.E., Hart, M.B., Leary, P.N., Tocher, B.A., Horne, D., Rosenfeld, A., 1988. Microfossil assemblages and the Cenomanian-Turonian (late Cretaceous) oceanic anoxic event. Cretaceous Research 9, 3-103. doi:101016/0195-6671(88)90003-1.

Jarvis, I., Gale, A.S., Jenkyns, H.C., Pearce, M.A., 2006. Secular variation in the Late Cretaceous carbon isotopes: a new $\mathrm{d} 13 \mathrm{C}$ carbonate reference curve for the Cenomanian-Campanian (99.6-70.6 Ma). Geological Magazine 143, 561-608.

Jefferies, R.P.S., 1962. The palaeoecology of the Actinocamax plenus Subzone (Lowest Turonian) in the Anglo-Paris Basin. Palaeontology 4, 609-647.

Jenkyns, H.C., 1980. Cretaceous anoxic events: from continents to oceans. Journal of the Geological Society of London 137, 171-188.

Jenkyns, H.C., 2003. Evidence for rapid climate change in the Mesozoic-Palaeogene greenhouse world. Philosophical Transactions of the Royal Society A: Mathematical, Physical and Engineering Sciences 361, 1885-1916.

Jenkyns, H.C., Gale, A.S., Corfield, R.M., 1994. Carbon- and oxygen-isotope stratigraphy of the English Chalk and Italian Scaglia and its palaeoclimatic significance. Geological Magazine 131, 1-34.

Jones, C.E., Jenkyns, H.C., 2001. Seawater strontium isotopes, oceanic anoxic events, and seafloor hydrothermal activity in the Jurassic and Cretaceous. American Journal of Science 301, 112-149.

Keller, G., Adatte, T., Berner, Z., Chellai, E.H., Stueben, D., 2008. Oceanic events and biotic effects of the Cenomanian-Turonian anoxic event, Tarfaya Basin, Morocco. Cretaceous Research 29, 976-994 doi:10.1016/j.cretres.2008.05.020.

Keller, G., Han, Q., Adatte, T., Burn, S.J., 2001. Palaeoenvironment of the Cenomanian-Turonian transition at Eastbourne, England. Cretaceous Research 22, 391-422.

Keller, G., Pardo, A., 2004. Age and paleoenvironment of the Cenomanian-Turonian global stratotype section and point at Pueblo, Colorado. Marine Micropaleontology 51, 95-128. doi:10.1016/j.marmicro.2003.08.004.

Kennedy, W.J., Walaszczyk, I., Cobban, W.A., 2000. Pueblo Colorado, USA, candidate Global Boundary Stratotype Section and Point for the base of the Turonian Stage of the Cretaceous, and for the base of the Middle Turonian Substage, with a revision of the Inoceramidae (Bivalvia). Acata Geologica Polonica 50, 295-334.

Kübler, B., 1983. Dosage quantitative des minéraux majeurs des roches sédimentaires par diffractionX. Cahier de l'Institut de Géologie, Université de Neuchâtel Suisse. Série ADX, 2.

Kuhn, O., Weissert, H., Föllmi, K.B., Hennig, S., 2005. Altered carbon cycling and trace-metal enrichment during the late Valanginian and early Hauterivian. Eclogae Geol Helv 98, 333-344.

Lamolda, M.A., Gorostidi, A., Martinez, R., Lopez, G., Peryt, D., 1997. Fossil occurrences in the Upper Cenomanian Lower Turonian at Ganuza, northern Spain: an approach to Cenomanian-Turonian boundary chronostratigraphy. Cretaceous Research 18, 331-353.

Leckie, R.M., 1985. Foraminifera of the Cenomanian-Turonian boundary interval, Greenhorn Formation, Rock Canyon Anticline, Pueblo, Colorado. In: Pratt, L.M. Kauffman, E.G., Zelt, F.B. (Eds.), Fine-grained Deposits and Biofacies of the Cretaceous Western Interior Seaway: Evidence of Cyclic Sedimentary Processes. Society of Economic Paleontologists and Mineralogists, Field Trip Guidebook, vol. 9, pp. 139-149.

Leckie, R.M., 1987. Paleoecology of the mid-Cretaceous planktic foraminifera: a comparison of open ocean and epicontinental sea assemblages. Micropaleontology 33, 164-176. doi:10.2307/1485491.

Leckie, R.M., Bralower, T.J., Cashman, R., 2002. Oceanic anoxic events and plankton evolution: biotic response to tectonic forcing during the mid-Cretaceous. Paleoceanography 17, PA 1041. doi:10.1029/2001PA000623.
Leckie, R.M., Schmidt, M.G., Finkelstein, D., Yuretich, R., 1991. Paleoceanography and paleoclimatic interpretations of the Mancos shale (Upper Cretaceous), Black Mesa Basin, Arizona. In: Nations, J.D., Eaton, J.G. (Eds.), Stratigraphy and Paleoenvironments of the Cretaceous Western Interior Seaway. SEPM Concepts in Sedimentology and Paleontology, vol. 6, pp. 101-126.

Leckie, R.M., Yuretich, R.F., West, L.O.L., Finkelstein, D., Schmidt, M., 1998. Paleoceanography of the southwestern interior Sea during the time of the Cenomanian-Turonian boundary (late Cretaceous). In: Dean, W.E., Arthur, M.A. (Eds.), Concepts in Sedimentology and Paleontology. SEPM, USA, pp. 101-126. vol. 6.

Loeblich, A.R., Tappan, H., 1988. Foraminiferal Genera and Their Classification. Van Nostrand Reinhold Company, New York. 970pp., 847 pl.

MacArthur, R.H., Wilson, E.O., 1967. The Theory of Island Biogeography. Princeston University Press, New Jersey. 203pp.

Montoya-Pino, C., Weyer, S., Anbar, A.D., Pross, J., Oschmann, W., van de Schootbrugge, B., Arz, H.W., 2010. Global enhancement of ocean anoxia during oceanic anoxic event 2: a quantitative approach using $U$ isotopes. Geology 38, 315-318.

Mort, M., Adatte, T., Föllmi, K.B., Keller, G., Steinmann, P., Matera, V., Berner, Z. Stüben, D., 2007. Phosphorus and the roles of productivity and nutrient recycling during oceanic event 2. Geology 35, 483-486.

Norris, R.D., Bice, K.L., Magno, E.A., Wilson, P.A., 2002. Jiggling the tropical thermostat in the Cretaceous hothouse. Geology 30, 299-302.

Nederbragt, A.J., Fiorentino, A., 1999. Stratigraphy and palaeoceanography of the Cenomanian-Turonian Boundary Event in Oued Mellegue, north-western Tunisia. Cretaceous Research 20, 47-62.

Pancost, R.D., Crawford, N., Magness, S., Turner, A., Jenkyns, H.C., Maxwell, J.R., 2004 Further evidence for the development of photic-zone euxinic conditions during mesozoic oceanic anoxic events. Journal of the Geological Society of London $161,353-364$.

Paul, C.R.C., Lamoldad, S.F., Mitchell, S.F., Vaziri, M.R., Gorostidib, A., Marshall, J.D., 1999. The Cenomanian-Turonian boundary at Eastbourne (Sussex, UK): a proposed European reference section. Palaeogeography, Palaeoclimatology, Palaeoecology 150 (1-2), 83-121.

Pearce, C.R., Jarvis, I., Tocher, B.A., 2009. The Cenomanian-Turonian boundary event, OAE 2 and palaeoenvironmental change in epicontinental seas: new insights from the dinocyst and geochemical records. Palaeogeography, Palaeoclimatology, Palaeoecology 280 (1-2), 207-234.

Pederson, T.F., Calvert, S.E., 1990. Anoxia vs. productivity: what controls the formation of organic carbon-rich sediments and sedimentary rock? Bulletin of the American Association of Petroleum Geologists 74, 454-466.

Petters, S.W., 1980. Foraminiferal paleoecology of Nigerian late Cretaceous epeiric seas. Annales de Muséum d'Histoire Naturelle de Nice 6, 82-133.

Pratt, L.M., Threlkeld, C.N., 1984. Stratigraphic significance of ${ }^{13} \mathrm{C} /{ }^{12} \mathrm{C}$ ratios in midCretaceous rocks of the Western Interior, USA. In: Stott, D.F., Glass, D.J. (Eds.), The Mesozoic of Middle North America. Canadian Society of Petroleum Geologists, Memoir, vol. 9, pp. 305-312.

Robaszynski, F., Caron, M., 1979. Atlas de foraminifères planctoniques du Crétacé moyen (Mer Boreale et Tethys), première partie. Cahiers de Micropaléontologie 1, 185

Robaszynski, F., Caron, M., 1995. Foraminifères planctoniques du Crétacé: commentaire de la zonation europe-méditerranée. Bulletin de la Société Géologique de France 166, 681-692.

Robaszynski, F., Zagrarni, M.F., Caron, M., Amédro, F., 2010. The global bio-event at the Cenomanian-Turonian transition in the reduced Bahloul Formation of Bou Ghanem (central Tunisia). Cretaceous Research 31, 1-15.

Sageman, B.B., Rich, J., Arthur, M.A., Dean, W.E., Savrda, C.E., Bralower, T.J., 1998 Multiple Milankovitch cycles in the Bridge Creek Limestone (CenomanianeTuronian), western Interior Basin. In: Arthur, M.A., Dean, W.E. (Eds.), Stratigraphy and Paleoenvironments of the CretaceousWestern Interior Seaway. Society of Economic Paleontologists and Mineralogists Concepts in Sedimentology and Paleontology 6, 153-171.

Sageman, B.B., Meyers, S.R., Arthur, M.A., 2006. Orbital time scale and new C-isotope record for Cenomanian-Turonian boundary stratotype. Geology 34, 125-128.

Schlanger, S.O., Jenkyns, H.C., 1976. Cretaceous oceanic anoxic event: causes and consequences. Geologie en Mijnbouw 55, 179-188.

Schlanger, S.O., Arthur, M.A., Jenkyns, H.C., Scholle, P.A., 1987. The CenomanianTuronian Oceanic Anoxic Event, I. Stratigraphy and Distribution of Organic Carbon-rich Beds and the Marine d13C Excursion. In: Geological Society, London, Special Publications, vol. 26. doi:10.1144/GSL.SP.1987.026.01.24 371-399.

Schrag, D.P., Depaolo, D.J., Richter, F.M., 1995. Reconstructing past sea surface temperatures: correcting for diagenesis of bulk marine carbonate. Geochimica et Cosmochimica Acta 59, 2265-2278.

Scholle, P.A., Arthur, M.A., 1980. Carbon isotope fluctuations in Cretaceous pelagic limestone: potential stratigraphic and petroleum exploration tool. American Association of Petroleum Geologists Bulletin 64, 67-87.

Scotese, C.R., 2001. Atlas of Earth History. PALEOMAP Project 1, 52.

Sinninghe Damsté, J.S., van Bentum, E.C., Reichart, G.-J., Pross, J., Schouten, S., 2010. A CO2 decrease-driven cooling and increased latitudinal tempareture gradien during the mid-Cretaceous Oceanic Anoxic Event 2. Earth and Planetary Science Letters 293, 97-103.

Snow, L.J., Duncan, R.A., Bralower, T.J., 2005. Trace element abundances in the Rock Canyon Anticline, Pueblo, Colorado, marine sedimentary section and their relationship to Caribbean plateau construction and ocean anoxic event 2 . Paleoceanography 20, PA3005. doi:10.1029/2004PA001093. 
Strasser, A., Caron, M., Gjermeni, M., 2001. The Aptian, Albian and Cenomanian of Roter Sattel, Romandes Prealps, Switzerland: a high-resolution record of oceanographic changes. Cretaceous Research 22, 173-199.

Takashima, R., Nishi, H., Yamanaka, T., Hayashi, K., Waseda, A., Obuse, A., Tomosugi, T., Deguchi, N., Mochizuki, S., 2010. High-resolution terrestrial carbon isotope and planktic foraminiferal records of the Upper-Cenomanian to the lower Campanian in the Northwest Pacific. Earth and Planetary Science Letters 289, 570-582.

Tribovillard, N., Algeo, T.J., Lyons, T.W., Riboulleau, A., 2006. Trace metals as paleoredox and paleoproductivity proxies: an update. Chemical Geology 232, 12-32.

Tsikos, H., Jenkyns, H.C., Walsworth-Bell, B., Petrizzo, M.R., Forster, A., Kolonic, S., Erba, E., Premoli Silva, I., Baas, M., Wagner, T., Sinninghe Damsté, J.S., 2004. Carbon-isotope stratigraphy recorded by the Cenomanian-Turonian Oceanic Anoxic Event: correlation and implications based on three key localities. Journal of the Geological Society of London 161, 711-719.

Turgeon, S., Brumsack, H.-J., 2006. Anoxic vs. dysoxic events reflected in sediment geochemistry during the Cenomanian-Turonian Boundary Event (Cretaceous) in the Umbria-Marche Basin of central Italy. Chemical Geology 234, 321-339.

Van Cappellen, P., Ingall, E.D., 1994. Benthic phosphorus regeneration, net primary production, and ocean anoxia: a model of the coupled marine biogeochemical cycles of carbon and phosphorus: Paleoceanography 9, 677-692.

Voigt, S., Aurag, A., Leis, F., Kaplan, U., 2007. Late Cenomanian to Middle Turonian high-resolution carbon isotope stratigraphy: new data from the Münsterland
Cretaceous Basin, Germany. Earth and Planetary Science Letters 235 (1-2), 196-210. doi:10.1016/j.epsl.2006.10.026.

Voigt, S , Gale, A.S. Flögel, S. 2004. Midlatitude shelf seas in the CenomanianTuronian greenhouse world: Temperature evolution and North Atlantic circulation. Paleoceanography 19 (PA4020), 1-17.

Voigt, S., Gale, A.S., Voigt, T., 2006. Sea-level change, carbon cycling and palaeoclimate during the Late Cenomanian of northwest Europe; an integrated palaeoenvironmental analysis. Cretaceous Research 27 (6), 836-858. doi:10.1016/j.cretres.2006.04.005.

Voigt, S., Erbacher, J., Mutterlose, J., Weiss, W., Westerhold, T., Wiese, F., Wilmsen, M., Wonik, T., 2008. The Cenomanian-Turonian of the Wunstorf section (North Germany): global stratigraphic reference section and new orbital time scale for oceanic anoxic event 2 . Newsletters on Stratigraphy 43 (1), $65-89$.

Wagreich, M., Bojar, A.-V., Sachsenhofer, R.F., Neuhuber, S., Egger, H., 2008. Calcareous nannoplanktonic foraminiferal, and carbonate carbon isotope stratigraphy of the Cenomanian-Turonian boundary section in the Ultrahelvetic zone (Eastern Alps, Upper Austria). Cretaceous Research 29, 965-975. doi:10.1016/ j.cretres.2008.05.017

Wilson, P.A., Norris, R.D., Cooper, M.J., 2002. Testing the Cretaceous greenhouse hypothesis using glassy foraminiferal calcite from the core of the Turonian tropics on Demerara Rise. Geology 30, 607-610. 